\title{
Growth Dynamics and Tree Shape of Common Beech (Fagus sylvatica L.) in the International Provenance Test
}

\author{
Mirzeta Memišević Hodžić1,*, Dalibor Ballian ${ }^{1}$
}

(1) University of Sarajevo, Faculty of Forestry, Zagrebačka 20, BA-71000 Sarajevo, Bosnia and Herzegovina

* Correspondence: e-mail: m.memisevic-hodzic@sfsa.unsa.ba

\begin{abstract}
Citation: Memišević Hodžić M, Ballian D, 2021. Growth Dynamics and Tree Shape of Common Beech (Fagus sylvatica L.) in the International Provenance Test. South-east Eur for 12(2): 105-114. https://doi.org/10.15177/seefor.21-11. Received: 8 Sep 2021; Revised: 8 Oct 2021; Accepted: 9 Oct 2021; Published online: 15 Nov 2021
\end{abstract}

\begin{abstract}
Provenance tests of forest tree species are important experiments in silviculture and tree breeding. Their results provide information about provenances' growth, adaptability, and other features. The research aimed to determine the dynamics of growth and tree shape of common beech plants per provenances in the international provenance test in Bosnia and Herzegovina to choose the best provenances considering wood production and quality. Research was conducted in the provenance test containing eight provenances from Bosnia and Herzegovina, four from Germany, three from Serbia, two each from Croatia, Romania, and Switzerland, and one from Hungary. Provenance test was established in 2007 by planting 2-year-old and 3-year old seedlings. Height and root collar diameter were measured, and tree shape was assessed in 2019. Data were processed in SPSS 26.0. Descriptive statistics, variance analysis, multiple Duncan's test for all traits, and Pearson's coefficient of corelation among morphological traits and tree shape were calculated. Variance for the height and root collar diameter showed statistically significant differences among different ages of plants and among provenances. Provenance from Croatia (Dilj Čaglinski) had the highest, and provenance from Romania (Alba-lulia) had the lowest average height. The highest average value of root collar diameter had provenance Dilj Čaglinski, and the lowest value had provenance Sihlwald (Switzerland). The highest percentage of category 10 (ideal tree form) had provenance Bad Wildbad (Germany), and categories 1-4 (no silviculture value) had provenance Alba-lulia (Romania). Pearson's coefficient showed that height, root collar diameter, and tree shape are highly correlated. Considering all the above, when planning forest-breeding works, it is recommended to continue the research and favor provenances with the best growth and tree shape.
\end{abstract}

Keywords: Fagus sylvatica; selection of provenances; wood productivity; wood quality

\section{INTRODUCTION}

Common beech (Fagus sylvatica L.) is the most common tree species in the total area of forests and forest lands in Bosnia and Herzegovina (Fukarek 1970), and researches on this species are especially significant. Studies of common beech provenances in different parts of its range indicated significant intra-population and inter-population variability (Kajba 2003).

Due to its importance, beech has been the subject of research by numerous scientists and researchers (Barriere et al. 1984, Kleinschmit 1985, Brus et al. 1990, Comps et al. 1991, 1998, Muhs and von Wuhlisch 1992, Gömöry et al. 1999, 2003, 2007, Gračan and Ivanković 2001, Gračan et al.
2006, Ivanković et al. 2008, 2011, Ballian and Zukić 2011, Ballian et al. 2012, Ballian et al. 2015, Ballian et al. 2019, Memišević Hodžić and Ballian 2021).

International experiments with common beech have been established intensively in recent decades due to the need to preserve the genetic resources of the species. In the early 1980s, the establishment of a network of field trials began (Muhs 1985). During that period, 15 experiments with 188 provenances were established. During the 1990s, new experiments were established and included the eastern part of the common beech range. Muhs et al. (1992) proved morphological, phenological, and genetic variability of common beech among and within populations. Muhs (1985) found that geographical variability is ecotypic rather than clinal. 
Hussendörfer et al. (1996) investigated phenotypic traits (branching type, forkiness) in a 12-year-old common beech stand in Switzerland. They concluded that there was no correlation between these traits and that it was not possible to identify their genetic determinants.

This research aimed to determine the dynamics of growth and the shape of the tree of common beech provenances in the international provenance test in Bosnia and Herzegovina, to select provenances with the best characteristics in terms of wood mass production and wood quality for further afforestation with this species. The aim was also to determine whether there were statistically significant differences in morphological traits of provenances according to the age of the seedlings at the time of establishing the provenance test.

\section{MATERIALS AND METHODS}

Plants from the international provenance test of common beech in Bosnia and Herzegovina were measured and assessed in this research. The test includes 22 provenances, eight from Bosnia and Herzegovina, four from Germany, three from Serbia, two from Croatia, two from Romania, two from Switzerland, and one provenance from Hungary (Table 1, Figure 1).

The test was established in a randomized block system with three replications, planting seedlings aged $2+0$ and $3+0$ with a planting interval of $2 \times 1 \mathrm{~m}$. The provenance test was erected in the spring of 2007 on a surface with average coordinates of $44^{\circ} 04^{\prime} 15^{\prime \prime} \mathrm{N} 18^{\circ} 11^{\prime} 32^{\prime \prime} \mathrm{E}$. Administratively, it belongs to the forest management area "Kakanjsko", forest management unit "Donja Trstionica - Goruša", department 41 , section c. It is located at 510 to $540 \mathrm{~m}$ above sea level. The average slope of the terrain is $7 \%$, and the exposure is mostly northeastern. Rendzina and acid brown soil complex, and a complex of acid brown and ilimerized soil predominate. Brown soils are present on a small part of the surface. The area is influenced by a temperate continental climate, characterized by cold winters and moderately warm summers with abundant precipitation.

In the spring of 2019, plant heights and root collar diameters were measured, and tree shape was assessed. Heights were measured using a stick meter and root collar

Table 1. Data of studied provenances.

\begin{tabular}{|c|c|c|c|c|c|c|c|c|}
\hline No & Label & Provenance & Country & Latitude & Longitude & Altitude & $\begin{array}{c}\text { Seedlings' age at the } \\
\text { time of establishing } \\
\text { the test }\end{array}$ & $\begin{array}{c}\text { Plants age at } \\
\text { the time of } \\
\text { measuring }\end{array}$ \\
\hline 1 & 9661 & B. Krupa Baštra Čorkovaća & $\mathrm{BiH}$ & $44^{\circ} 45^{\prime}$ & $16^{\circ} 14^{\prime}$ & 720 & $2+0$ & 14 \\
\hline 2 & 9659 & Bugojno Vranica - Bistrica & $\mathrm{BiH}$ & $43^{\circ} 33^{\prime}$ & $17^{\circ} 49^{\prime}$ & 750 & $2+0$ & 14 \\
\hline 3 & 9662 & Dinara & $\mathrm{BiH}$ & $44^{\circ} 06^{\prime}$ & $16^{\circ} 30^{\prime}$ & 950 & $2+0$ & 14 \\
\hline 4 & 9633 & Grmeč - Jasenica & $\mathrm{BiH}$ & $44^{\circ} 16^{\prime}$ & $16^{\circ} 18^{\prime}$ & 450 & $3+0$ & 15 \\
\hline 5 & 9631 & Konjuh - Kladanj & $\mathrm{BiH}$ & $44^{\circ} 16^{\prime}$ & $18^{\circ} 34^{\prime}$ & 840 & $3+0$ & 15 \\
\hline 6 & 9630 & Tajan - Zavidovići & $\mathrm{BiH}$ & $44^{\circ} 23^{\prime}$ & $18^{\circ} 03^{\prime}$ & 700 & $3+0$ & 15 \\
\hline 7 & 9632 & Tešanj - Crni Vrh I & $\mathrm{BiH}$ & $44^{\circ} 33^{\prime}$ & $17^{\circ} 59^{\prime}$ & 500 & $3+0$ & 15 \\
\hline 8 & 9660 & Tešanj - Crni Vrh II & $\mathrm{BiH}$ & $44^{\circ} 33^{\prime}$ & $17^{\circ} 59^{\prime}$ & 500 & $2+0$ & 14 \\
\hline 9 & 9624 & Dilj Čanglinski & $\mathrm{HR}$ & $45^{\circ} 17^{\prime}$ & $18^{\circ} 01^{\prime}$ & 350 & $3+0$ & 15 \\
\hline 10 & 9625 & Vran kamen & $\mathrm{HR}$ & $45^{\circ} 37^{\prime}$ & $17^{\circ} 19^{\prime}$ & 600 & $3+0$ & 15 \\
\hline 11 & 9646 & Bad Wildbad & D & $48^{\circ} 46^{\prime}$ & $08^{\circ} 35^{\prime}$ & 700 & $3+0$ & 15 \\
\hline 12 & 9642 & Valkonya & $\mathrm{H}$ & $46^{\circ} 30^{\prime}$ & $16^{\circ} 45^{\prime}$ & 300 & $3+0$ & 15 \\
\hline 13 & 9649 & Hasbruch & D & $53^{\circ} 08^{\prime}$ & $08^{\circ} 26^{\prime}$ & 35 & $3+0$ & 15 \\
\hline 14 & 9648 & Hoellerbach & D & $49^{\circ} 01^{\prime}$ & $13^{\circ} 14^{\prime}$ & 755 & $3+0$ & 15 \\
\hline 15 & 9647 & Schwäbisch Alb & D & $48^{\circ} 00^{\prime}$ & $10^{\circ} 00^{\prime}$ & 650 & $3+0$ & 15 \\
\hline 16 & 9663 & Alesd & RO & $46^{\circ} 10^{\prime}$ & $22^{\circ} 15^{\prime}$ & 490 & $2+0$ & 14 \\
\hline 17 & 9664 & Alba-lulia & RO & $46^{\circ} 10^{\prime}$ & $23^{\circ} 05^{\prime}$ & 860 & $2+0$ & 14 \\
\hline 18 & 9666 & Avala & SRB & $44^{\circ} 12^{\prime}$ & $20^{\circ} 45^{\prime}$ & 745 & $2+0$ & 14 \\
\hline 19 & 9669 & Cer & SRB & $44^{\circ} 12^{\prime}$ & $19^{\circ} 50^{\prime}$ & 745 & $2+0$ & 14 \\
\hline 20 & 9668 & Fruška gora & SRB & $45^{\circ} 10^{\prime}$ & $19^{\circ} 47^{\prime}$ & 360 & $2+0$ & 14 \\
\hline 21 & 9643 & Herzogenbuchsee & $\mathrm{CH}$ & $07^{\circ} 40^{\prime}$ & $47^{\circ} 11^{\prime}$ & 500 & $3+0$ & 15 \\
\hline 22 & 9665 & Sihlwald & $\mathrm{CH}$ & $47^{\circ} 12^{\prime}$ & $07^{\circ} 21^{\prime}$ & 1050 & $2+0$ & 14 \\
\hline
\end{tabular}




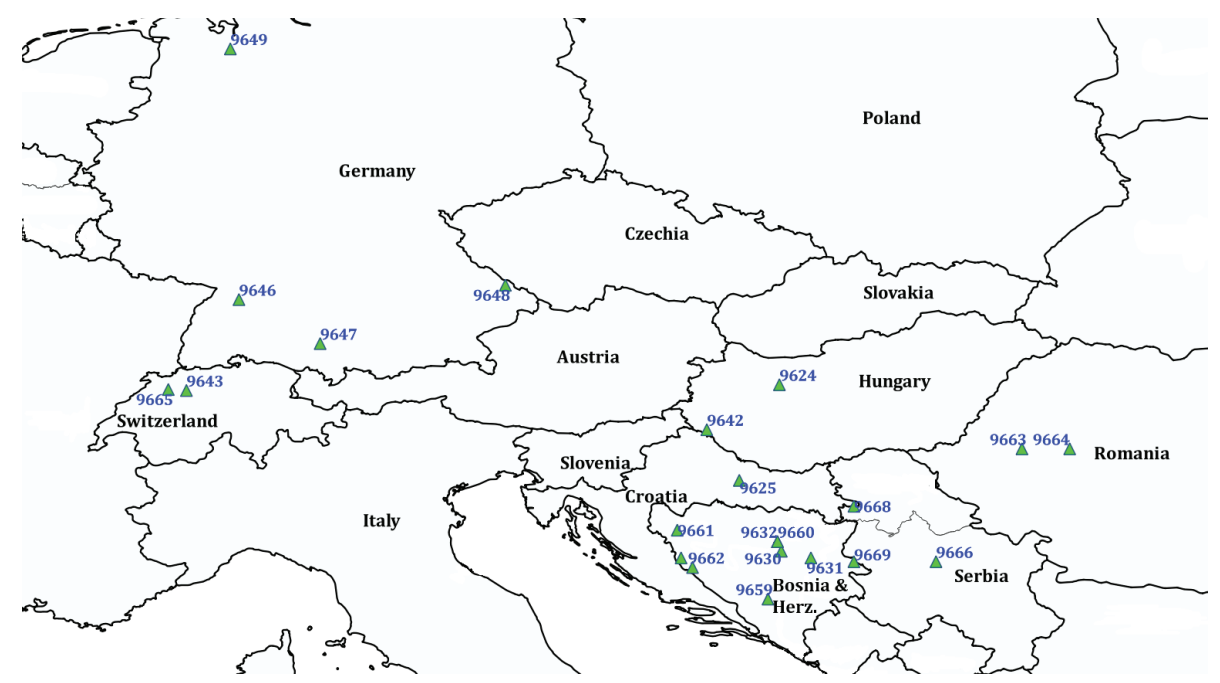

Figure 1. Researched provenances.

diameter using an electronic moving scale. Tree shape was evaluated according to the scoring system for beech and oak as shown in Figure 2 (Ducci et al. 2012). Trees that did not meet the criteria of cultivation value were marked by a common designation 1-4.

Data on height and root collar diameters were processed by the statistical program SPSS 26.0. Descriptive indicators, variance analysis, and Duncan's test were calculated according to the provenances and ages of the plants. Tree shape data were also processed in the SPSS 26.0 program. Frequencies of categories were calculated per provenances. The Pearson's correlation coefficient for height, root collar diameter, and tree shape was calculated.
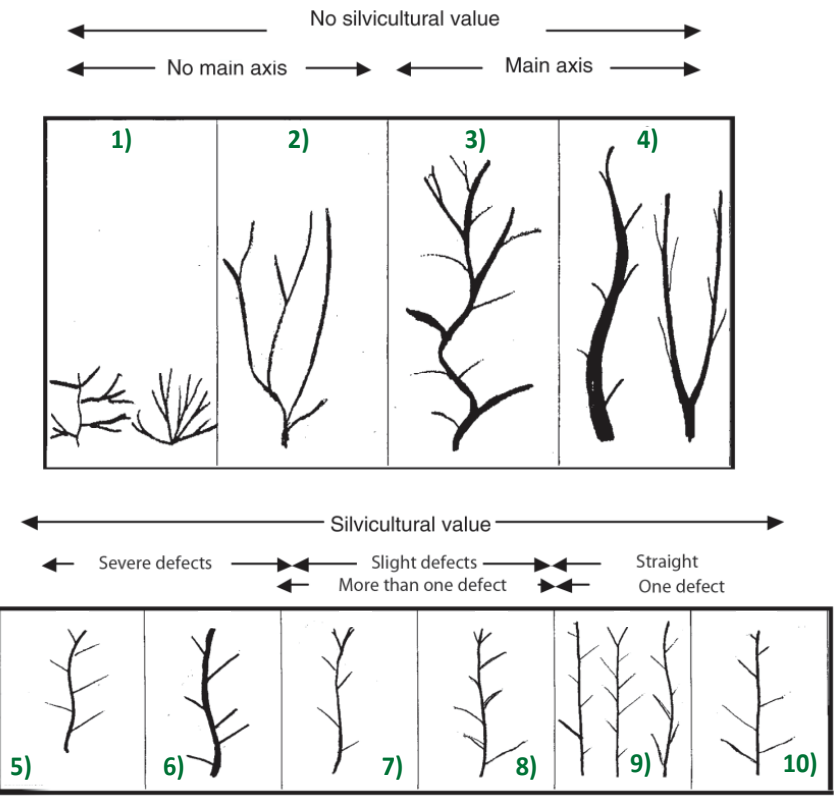

Figure 2. The scoring system used for beech and oak (Ducci et al. 2012).
1) No main stem or on a low height ("apple" shape);

2) no apparent stem; very many major defects;

3) presence of a visible stem, but several major defects;

4) presence of a visible stem, but a major defects eliminates any forestry quality;

5) trees having many defects (branching angle, branches diameter, branches' density, flexuosity), but could be recovered with pruning;

6) a big defects that could be recovered, or more mean defects;

7) two means defects or many small defects; maximum score for a tree with multiple stem;

8) two slight defects, or means defect;

9) a small defect (fork at the top of the crown, slight flexuosity, branches with greater average diameters,...);

10) ideal tree: no default. 


\section{RESULTS}

\section{Heights}

Average values of heights according to plant ages are shown in Table 2.

The average height of provenances whose seedlings were $2+0$ years old when establishing the provenance test was lower than the average height of those whose seedlings were $3+0$ years old. T-test according to plant age (Table 3) showed that the differences caused by differences in seedlings' age were statistically significant (Sig. <0.05).

Average values of heights by provenances are shown in Table 4.

Provenance from Croatia (Dilj Čanglinski) had the tallest trees, the average height of $262.9 \mathrm{~cm}$, while provenance from Romania (Alba-Iulia) had the lowest trees, and the average height of $161.3 \mathrm{~cm}$. The second-highest average height had provenance Vran Kamen (Croatia) with 243.4 $\mathrm{cm}$, and the third Konjuh - Kladanj (Bosnia and Herzegovina) with $241.80 \mathrm{~cm}$.

When it comes to provenances with lower average heights, after Alba-lulia, another provenance from Romania (Alesd) had a low average height $(165.0 \mathrm{~cm})$ and provenance from Switzerland (Sihlwald) $(172.4 \mathrm{~cm})$. Plants of provenances with higher average heights at the time of measurement were 15 years old, and plants of provenances with lower heights were 14 years old.

Analysis of variance for height (Table 5) shows statistically significant differences among provenances ( $F$ calculated $>\mathrm{F}$ in the table, Significance $<0.005$ ).

The results of the Duncan's test for height showed a grouping of provenances into six groups that overlap (showed in Table 4).

\section{Root Collar Diameter}

Table 6 shows the average values of root collar diameter according to plant ages in the provenance test.

As for the heights, average values of root collar diameters of 14 year-old plants were lower than the average values of provenances with 15 years old plants. T-test according to plant age (Table 7) showed statistically significant differences per plants' age (Sig. <0.05).

Table 8 shows the average values of root collar diameter $(\mathrm{mm})$ per provenances.

The highest average value of the root collar diameter had the provenance from Croatia (Dilj Čanglinski) with 48.9 $\mathrm{mm}$. The second highest value had provenance Vran Kamen with $45.8 \mathrm{~mm}$ and the third Tešanj Crni Vrh I with 45.4 $\mathrm{mm}$. The lowest average size of root collar diameter had provenance Sihlwald from Switzerland with $29.5 \mathrm{~mm}$, then provenances from Romania, Alba-lulia $30.7 \mathrm{~mm}$, and Alesd $32.6 \mathrm{~mm}$. As for the root collar diameter, provenances with 14 year-old plants had lower values of root collar diameter than provenances with 15 year-old plants.

Variance analysis for root collar diameter (Table 9) showed statistically significant differences among provenances ( $F$ calculated $>F$ in the table, Significance $<0.005)$.

Duncan's test for root collar diameter showed a grouping of provenances into eight groups, which overlap each other.

\section{Tree Shape}

Figure 3 shows the percentages of plants with tree shape categories for all provenances together. The highest number of trees belong to category 10 (perfectly flat tree), and shapes without significance for forest cultivation occupy $9.8 \%$ of plants (Categories $1-4$ ) .

Table 2. Descriptive statitstics for height according to plants' age.

\begin{tabular}{cccccc}
\hline $\begin{array}{c}\text { Plants' age } \\
\text { (years) }\end{array}$ & $\begin{array}{c}\text { Average height } \\
(\mathrm{cm})\end{array}$ & $\begin{array}{c}\text { Standard deviations } \\
(\mathrm{cm})\end{array}$ & $\begin{array}{c}\text { Standard error } \\
(\mathrm{cm})\end{array}$ & $\begin{array}{c}\text { Minimum } \\
(\mathrm{cm})\end{array}$ & $\begin{array}{c}\text { Maximum } \\
(\mathrm{cm})\end{array}$ \\
\hline 14 & 206.0 & 75.9 & 4.6 & 55 & 420 \\
15 & 230.4 & 82.1 & 3.0 & 55 & 530 \\
\hline Average & 223.7 & 81.1 & 2.5 & 55 & 530 \\
\hline
\end{tabular}

Table 3. T-test for height per plants' age.

\begin{tabular}{|c|c|c|c|c|c|c|c|c|c|}
\hline & \multicolumn{2}{|c|}{$\begin{array}{l}\text { Levene's Test for } \\
\text { Equality of Variances }\end{array}$} & \multicolumn{7}{|c|}{ t-test for Equality of Means } \\
\hline & \multirow[t]{2}{*}{$\mathrm{F}$} & \multirow{2}{*}{ Sig. } & \multirow{2}{*}{$\mathbf{t}$} & \multirow{2}{*}{ df } & \multirow{2}{*}{$\begin{array}{c}\text { Sig. } \\
\text { (2-tailed) }\end{array}$} & \multirow{2}{*}{$\begin{array}{c}\text { Mean } \\
\text { Difference }\end{array}$} & \multirow{2}{*}{$\begin{array}{l}\text { Std. Error } \\
\text { Difference }\end{array}$} & \multicolumn{2}{|c|}{$\begin{array}{l}\text { 95\% Confidence Interval } \\
\text { of the Difference }\end{array}$} \\
\hline & & & & & & & & Lower & Upper \\
\hline $\begin{array}{l}\text { Equal variances } \\
\text { assumed }\end{array}$ & 553.599 & 0.000 & -14.952 & 3066 & 0.000 & -59.20579 & 3.95962 & -66.9696 & -51.4420 \\
\hline $\begin{array}{l}\text { Equal variances } \\
\text { not assumed }\end{array}$ & & & -15.299 & 2937.144 & 0.000 & -59.20579 & 3.86981 & -66.7936 & -51.6180 \\
\hline
\end{tabular}


Table 4. Descriptive statitstics for height per provenances.

\begin{tabular}{|c|c|c|c|c|c|c|c|}
\hline Provenance & Age & $\begin{array}{l}\text { Average height } \\
(\mathrm{cm})\end{array}$ & $\begin{array}{l}\text { Standard deviation } \\
(\mathrm{cm})\end{array}$ & $\begin{array}{l}\text { Standard Error } \\
(\mathrm{cm})\end{array}$ & $\begin{array}{l}\text { Minimum } \\
(\mathrm{cm})\end{array}$ & $\begin{array}{l}\text { Maximum } \\
(\mathrm{cm})\end{array}$ & $\begin{array}{c}\text { Group by } \\
\text { Duncan's test }\end{array}$ \\
\hline 9624 & 15 & 262.9 & 99.9 & 10.9 & 70 & 530 & 6 \\
\hline 9625 & 15 & 243.4 & 86.8 & 9.8 & 65 & 440 & $5 / 6$ \\
\hline 9630 & 15 & 238.3 & 81.3 & 9.7 & 110 & 440 & $5 / 6$ \\
\hline 9631 & 15 & 241.8 & 99.5 & 17.9 & 55 & 450 & $5 / 6$ \\
\hline 9632 & 15 & 239.9 & 93.1 & 14.2 & 85 & 420 & $5 / 6$ \\
\hline 9633 & 15 & 230.8 & 73.9 & 9.5 & 95 & 390 & $4 / 5 / 6$ \\
\hline 9642 & 15 & 235.3 & 73.2 & 8.0 & 80 & 395 & $4 / 5 / 6$ \\
\hline 9643 & 15 & 232.0 & 80.9 & 10.1 & 70 & 410 & $4 / 5 / 6$ \\
\hline 9646 & 15 & 178.4 & 49.8 & 10.0 & 100 & 290 & $1 / 2 / 3$ \\
\hline 9647 & 15 & 216.8 & 68.4 & 7.6 & 60 & 400 & $3 / 4 / 5$ \\
\hline 9648 & 15 & 209.9 & 67.3 & 9.9 & 85 & 360 & $2 / 3 / 4 / 5$ \\
\hline 9649 & 15 & 200.6 & 69.5 & 8.0 & 70 & 350 & $1 / 2 / 3 / 4 / 5$ \\
\hline 9659 & 14 & 217.9 & 85.9 & 16.2 & 105 & 420 & $3 / 4 / 5$ \\
\hline 9660 & 14 & 240.6 & 101.8 & 20.0 & 60 & 410 & $5 / 6$ \\
\hline 9661 & 14 & 193.1 & 47.9 & 10.4 & 100 & 280 & $1 / 2 / 3 / 4$ \\
\hline 9662 & 14 & 221.4 & 65.3 & 10.1 & 100 & 370 & $4 / 5 / 6$ \\
\hline 9663 & 14 & 165.0 & 53.8 & 10.6 & 55 & 330 & 1 \\
\hline 9664 & 14 & 161.3 & 73.3 & 18.9 & 60 & 280 & 1 \\
\hline 9665 & 14 & 172.4 & 64.9 & 12.3 & 80 & 305 & $1 / 2$ \\
\hline 9666 & 14 & 230.3 & 69.0 & 12.8 & 90 & 350 & $4 / 5 / 6$ \\
\hline 9668 & 14 & 212.7 & 75.2 & 14.2 & 60 & 400 & $2 / 3 / 4 / 5$ \\
\hline 9669 & 14 & 210.9 & 76.0 & 13.0 & 70 & 340 & $2 / 3 / 4 / 5$ \\
\hline \multicolumn{2}{|c|}{ Average } & 223.7 & 81.1 & 2.5 & 55 & 530 & - \\
\hline
\end{tabular}

Table 5. Variance analysis for height of the provenances.

\begin{tabular}{lccccc}
\multicolumn{1}{c}{ Source of variability } & Sum of Squares & df & Mean Square & F & Sig. \\
\hline Between Groups & 578576.925 & 21 & 27551.282 & 4.486 & 0.000 \\
Within Groups & 6122980.590 & 997 & 6141.405 & & \\
\hline Total & 6701557.515 & 1018 & & \\
\hline
\end{tabular}

Table 6. Descriptive statitstics for root collar diameter according to plants' age

\begin{tabular}{cccccc}
\hline $\begin{array}{c}\text { Plants' age } \\
\text { (years) }\end{array}$ & $\begin{array}{c}\text { Average root collar diameter } \\
(\mathrm{mm})\end{array}$ & $\begin{array}{c}\text { Standard deviations } \\
(\mathrm{mm})\end{array}$ & $\begin{array}{c}\text { Standard error } \\
(\mathrm{mm})\end{array}$ & $\begin{array}{c}\text { Minimum } \\
(\mathrm{mm})\end{array}$ & $\begin{array}{c}\text { Maximum } \\
(\mathrm{mm})\end{array}$ \\
\hline 14 & 7.5 & 16.2 & 0.4 & 0.01 & 80.4 \\
15 & 19.0 & 23.1 & 0.6 & 0.01 & 89.5 \\
\hline Average & 13.7 & 21.0 & 0.4 & 0.01 & 89.5 \\
\hline
\end{tabular}


Table 7. T-test for root collar diameter per plants' age.

\begin{tabular}{|c|c|c|c|c|c|c|c|c|c|}
\hline & \multicolumn{2}{|c|}{$\begin{array}{l}\text { Levene's Test for } \\
\text { Equality of Variances }\end{array}$} & \multicolumn{7}{|c|}{ t-test for Equality of Means } \\
\hline & \multirow[t]{2}{*}{$\mathbf{F}$} & \multirow[t]{2}{*}{ Sig. } & \multirow[t]{2}{*}{$\mathbf{t}$} & \multirow[t]{2}{*}{ df } & \multirow[t]{2}{*}{$\begin{array}{c}\text { Sig. } \\
\text { (2-tailed) }\end{array}$} & \multirow[t]{2}{*}{$\begin{array}{c}\text { Mean } \\
\text { Difference }\end{array}$} & \multirow[t]{2}{*}{$\begin{array}{l}\text { Std. Error } \\
\text { Difference }\end{array}$} & \multicolumn{2}{|c|}{$\begin{array}{l}95 \% \text { Confidence } \\
\text { Interval of the } \\
\text { Difference }\end{array}$} \\
\hline & & & & & & & & Lower & Upper \\
\hline $\begin{array}{l}\text { Equal variances } \\
\text { assumed }\end{array}$ & 632.107 & 0.000 & -15.854 & 3098 & .000 & -11.54696 & .72832 & -12.9750 & -10.1189 \\
\hline $\begin{array}{l}\text { Equal variances } \\
\text { not assumed }\end{array}$ & & & -16.278 & 2985.931 & .000 & -11.54696 & .70934 & -12.9378 & -10.1561 \\
\hline
\end{tabular}

Table 8. Descriptive statistics of root collar diameter per provenances.

\begin{tabular}{|c|c|c|c|c|c|c|c|}
\hline Provenance & $\begin{array}{c}\text { Age } \\
\text { (years) }\end{array}$ & $\begin{array}{l}\text { Average root collar } \\
\text { diameter } \\
(\mathrm{mm})\end{array}$ & $\begin{array}{l}\text { Standard } \\
\text { deviation } \\
(\mathrm{mm})\end{array}$ & $\begin{array}{l}\text { Standard } \\
\text { error } \\
(\mathrm{mm})\end{array}$ & $\begin{array}{l}\text { Minimum } \\
(\mathrm{mm})\end{array}$ & $\begin{array}{l}\text { Maximum } \\
(\mathrm{mm})\end{array}$ & $\begin{array}{l}\text { Group according } \\
\text { to Duncan's test }\end{array}$ \\
\hline 9624 & 15 & 48.9 & 13.5 & 1.5 & 22.9 & 80.5 & 6 \\
\hline 9625 & 15 & 45.8 & 13.6 & 1.5 & 20.4 & 81.7 & $5 / 6$ \\
\hline 9630 & 15 & 44.4 & 15.7 & 1.9 & 18.4 & 89.5 & $5 / 6$ \\
\hline 9631 & 15 & 43.9 & 12.9 & 2.3 & 19.1 & 73.0 & $4 / 5 / 6$ \\
\hline 9632 & 15 & 45.5 & 16.8 & 2.6 & 19.9 & 83.4 & $5 / 6$ \\
\hline 9633 & 15 & 42.6 & 13.7 & 1.8 & 17.7 & 82.8 & $4 / 5 / 6$ \\
\hline 9642 & 15 & 44.2 & 13.0 & 1.4 & 21.3 & 75.0 & $4 / 5 / 6$ \\
\hline 9643 & 15 & 40.7 & 13.0 & 1.6 & 16.6 & 81.7 & $5 / 6 / 7$ \\
\hline 9646 & 15 & 33.2 & 7.2 & 1.4 & 18.3 & 50.4 & $1 / 2 / 3 / 4$ \\
\hline 9647 & 15 & 40.0 & 12.3 & 1.4 & 22.3 & 77.6 & $5 / 6 / 7$ \\
\hline 9648 & 15 & 37.2 & 11.1 & 1.6 & 18.4 & 56.8 & $2 / 3 / 4 / 5 / 6$ \\
\hline 9649 & 15 & 39.4 & 10.4 & 1.2 & 20.6 & 73.8 & $4 / 5 / 6 / 7$ \\
\hline 9659 & 14 & 41.1 & 13.8 & 2.6 & 25.3 & 68.9 & $5 / 6 / 7$ \\
\hline 9660 & 14 & 40.8 & 16.4 & 3.2 & 14.7 & 80.4 & $5 / 6 / 7$ \\
\hline 9661 & 14 & 34.4 & 6.8 & 1.5 & 22.8 & 46.2 & $1 / 2 / 3 / 4 / 5$ \\
\hline 9662 & 14 & 45.4 & 12.4 & 1.9 & 25.6 & 70.3 & $5 / 6$ \\
\hline 9663 & 14 & 32.6 & 7.2 & 1.4 & 24.5 & 52.4 & $1 / 2 / 3$ \\
\hline 9664 & 14 & 30.7 & 9.0 & 2.3 & 18.5 & 42.9 & $1 / 2$ \\
\hline 9665 & 14 & 29.5 & 9.4 & 1.8 & 13.5 & 52.0 & 1 \\
\hline 9666 & 14 & 43.0 & 12.0 & 2.2 & 20.4 & 64.0 & $4 / 5 / 6$ \\
\hline 9668 & 14 & 40.1 & 10.5 & 2.0 & 19.6 & 61.4 & $5 / 6 / 7$ \\
\hline 9669 & 14 & 39.1 & 12.2 & 2.1 & 18.3 & 71.6 & $3 / 4 / 5 / 6 / 7$ \\
\hline \multicolumn{2}{|c|}{ Average } & 41.6 & 13.4 & 0.4 & 13.5 & 89.5 & \\
\hline
\end{tabular}

Table 9. Variance analysis of root collar diameter per provenance.

\begin{tabular}{lrrcrl}
\hline Source of variability & Sum of Squares & df & Mean Square kvadrata & F & Sig. \\
\hline Between Groups & 21155.683 & 21 & 1007.413 & 6.216 & 0.000 \\
Within Groups & 161568.944 & 997 & 162.055 & & \\
\hline Total & 182724.627 & 1018 & & & \\
\hline
\end{tabular}


Figure 4 shows the percentages of tree shape categories per provenances.

The highest percentage of category 10 had provenance 9646 (Bad Wildbad, Germany). Provenance 9664 (AlbaIulia, Romania) had the highest share of categories 1-4 (no cultivation value).

If we analyze only categories 8,9 , and 10 , as categories of trees with good shape, Baštra Ćorkovača from Bosnia and Herzegovina stands out with $76.2 \%$ of plants in these categories, Bad Wildbad from Germany with $72.0 \%$, Dilj
Čaglinski from Croatia with 69.0\%, and Herzogenbuchsee from Switzerland with $68.8 \%$.

\section{Correlation of Tree Shape, Height, and Root Collar} Diameter

Table 10 presents the values of the Pearson's correlation coefficient of investigated traits: tree shape, height, and root collar diameter.

Pearson's correlation coefficient showed high values of correlation among all three examined properties (height, root collar diameter, and tree shape).
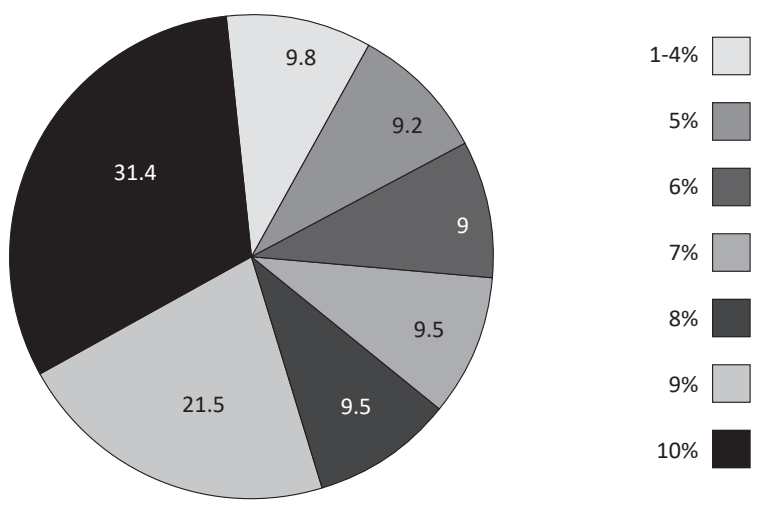

Figure 3. Percentages of plants per tree shapes categories for all provenances.

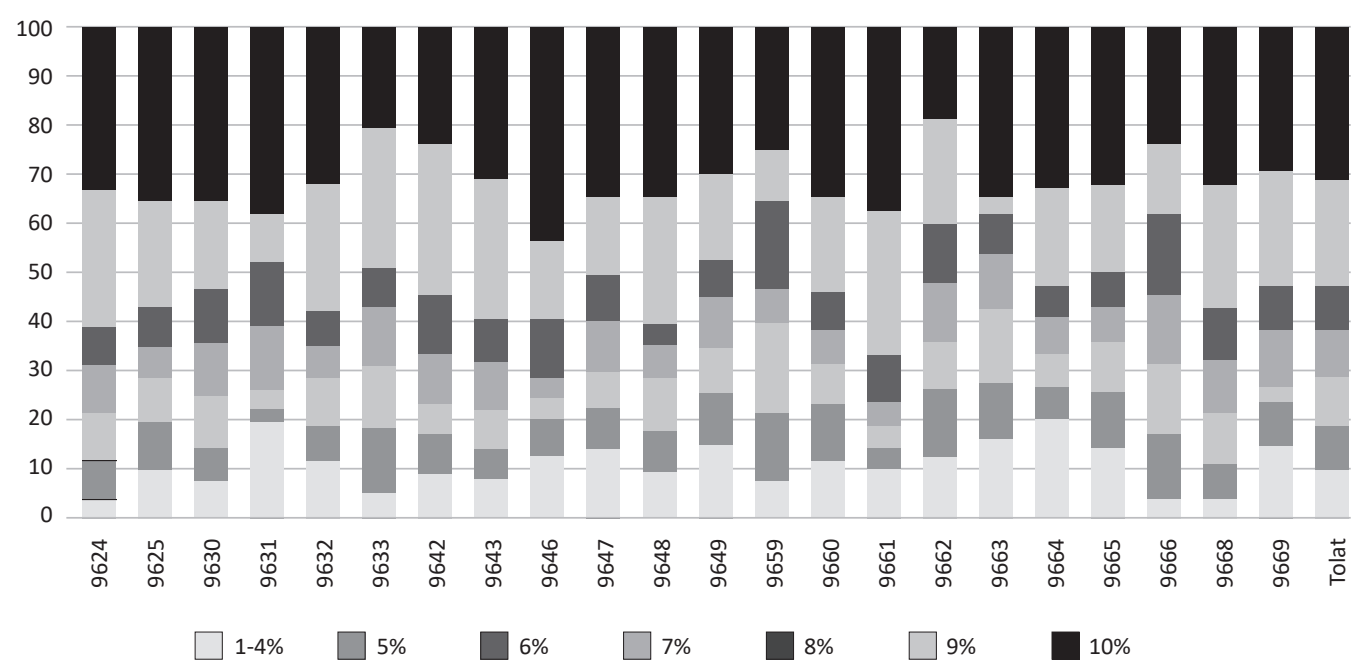

Figure 4. Percentages of plants per tree shape categories per provenance. 
Table 10. Pearson's correlation coefficient of tree shape, height, and root collar diameter.

\begin{tabular}{|c|c|c|c|c|}
\hline Traits & Pearson's correlation coefficient & Tree shape & Height & $\begin{array}{l}\text { Root collar } \\
\text { diameter }\end{array}$ \\
\hline \multirow{5}{*}{$\begin{array}{l}\text { Tree } \\
\text { shape }\end{array}$} & Pearson's Correlation & 1 & $0.931^{* *}$ & $0.929^{* *}$ \\
\hline & Sig. (2-tailed) & & 0.000 & 0.000 \\
\hline & Sum of Squares and Cross-products & 46864.699 & 1220252.887 & 228498.360 \\
\hline & Covariance & 15.627 & 410.860 & 76.192 \\
\hline & $\mathrm{N}$ & 3000 & 2971 & 3000 \\
\hline \multirow{5}{*}{ Height } & Pearson's Correlation & $0.931^{* *}$ & 1 & $0.975^{* *}$ \\
\hline & Sig. (2-tailed) & 0.000 & & .000 \\
\hline & Sum of Squares and Cross-products & 1220252.887 & 39376906.780 & 7033261.658 \\
\hline & Covariance & 410.860 & 12838.900 & 2293.206 \\
\hline & $\mathrm{N}$ & 2971 & 3068 & 3068 \\
\hline \multirow{5}{*}{$\begin{array}{l}\text { Root } \\
\text { collar } \\
\text { diameter }\end{array}$} & Pearson's Correlation & $0.929^{* *}$ & $0.975^{* *}$ & 1 \\
\hline & Sig. (2-tailed) & 0.000 & 0.000 & \\
\hline & Sum of Squares and Cross-products & 228498.360 & 7033261.658 & 1368664.902 \\
\hline & Covariance & 76.192 & 2293.206 & 441.647 \\
\hline & $\mathrm{N}$ & 3000 & 3068 & 3100 \\
\hline
\end{tabular}

\section{DISCUSSION}

Almost all previous research of common beech provenances treated morphological characteristics, especially height, diameter, and survival of plants, and results showed statistically significant differences among provenances (Ballian and Zukić 2011, Ballian and Jukić 201415, Bogunović et al. 2020, Memišević Hodžić and Ballian 2021, Popović et al. 2021). Ivanković et al. 2008 identified statistically significant differences among provenances in a provenance test in Slovenia, but in the same research, in a provenance test in Croatia, the effects of provenances were not statistically significant. Hoffman (1961) stated that the heights that reached a younger age cannot be taken as a reliable measure for determining the growth of provenances because changes in growth rate often occur at a later age. Some authors stated that conclusions about the growth of provenances are not reliable up to the age of 40 or one-third of the production period (Vidaković and Krstinić 1985, Kleinschmit 1985). Therefore, given the age of the provenances in this research, we still cannot reliably talk about the productivity of individual provenances, but the results are significant for the juvenile-adult correlation of investigated traits. Larsen (1985), based on an early test, stated that it is possible to predict that individual beech populations will maintain good growth at a later age. Therefore, this research results could help to obtain a general picture of all provenances and to predict their growth at a later age.

The highest values of the investigated traits had provenance from Croatia Dilj Čanglinski and the lowest AlbaIulia from Romania, which is in accordance with the results of the research by Memišević Hodžić and Ballian (2021).
This study also showed statistically significant differences between different ages of provenances.

In this paper, tree shape as an important indicator of the quality of the produced wood mass was also evaluated. The results showed statistically significant differences among the investigated provenances. The best tree shape had the provenance from Bosnia and Herzegovina (Baštra Čorkovaća). Also, provenances from Croatia and Germany had a large percentage of plants with good tree shape.

Correlation results among the growth properties (height and root collar diameter) and tree shape showed high values of the correlation among all three traits. Although there were no many studies on the correlation among morphological traits in common beech, Hussendörfer et al. (1996) investigated different types of branching and forkiness in 12-year-old common beech stand in Switzerland. They found no correlation among the traits and concluded that it is not possible to identify their genetic determinants.

Memišević Hodžić and Ballian (2020) investigated the shape of the pedunculate oak tree in Bosnian-Herzegovinian provenance test. The share of tree shape categories was less favorable, and only $14 \%$ of the total number of plants had the form of tree 10 according to the protocol of Ducci et al. (2012).

\section{CONCLUSIONS}

Analysis of variance for researched morphological traits (root collar diameter and height) showed statistically significant differences among the provenances, which was confirmed by Duncan's test. T-test showed statistically significant differences between plants of different ages. 
Provenances whose plants were 15 years old at the time of the study had higher average values of traits, which implies that the age of seedlings is an important factor to consider for artificial afforestation. The highest average plant height in 2019 had the provenance from Croatia (Dilj Changlinski) with $262.90 \mathrm{~cm}$, while the lowest average height had provenance from Romania (Alba-lulia) with $161.30 \mathrm{~cm}$. The highest average value of root collar diameter had the provenance from Croatia (Dilj Čanglinski) with $48.9 \mathrm{~mm}$, while the lowest average value had the provenance from Switzerland (Sihlwald) with $29.5 \mathrm{~mm}$. The provenances of Baštra Ćorkovača from Bosnia and Herzegovina, Bad Wildbad from Germany, and Dilj Čaglinski from Croatia have the best ratio of the percentage of trees of different categories of tree shapes. The correlation coefficient showed values of approximately 1 , which indicates a positive correlation, i.e., provenances with higher increments in height and thickness also have a better tree shape. The results of this research are important for having a general picture of provenances' growth, and should be continued to determine the juvenileadult correlation of these traits in common beech.

\section{Author Contributions}

$\mathrm{MMH}$ and DB conceived and designed the research; DB carried out the field measurements; $\mathrm{MMH}$ and $\mathrm{DB}$ processed the data and performed statistical analysis; $\mathrm{MMH}$ and $\mathrm{DB}$ supervised the research; $\mathrm{MMH}$ and $\mathrm{DB}$ wrote the manuscript.

\section{Funding}

The research had no funding support.

\section{Conflicts of Interest}

The authors declare no conflict of interest.

\section{REFERENCES}

Ballian D, Bogunić F, Mujezinović O, Kajba D, 2012. Genetic Differentation of European Beech (Fagus sylvatica L.) in Bosnia and Herzegovina. Sumar List 136(11-12): 587-595. [in Croatian with English summary]

Ballian D, Jukić B, Balić B, Kajba D, Von Wüehlisch G, 2015. Phenological Variability of European Beech (Fagus sylvatica L.) in the International provenance Trial. Sumar List 139(11-12): 521533. [in Croatian with English summary]

Ballian D, Jukić B, 2014-15. Usporedni pokazatelji uspijevanja bukve (Fagus sylvatica L.) u međunarodnom pokusu Kakanj za 2009. i 2014. godinu. Radovi Hrvatskoga društva za znanost i umjetnost 16/17: 200-215. [in Croatian]

Ballian D, Westergern M, Kraigher H, 2019. Varijabilnost obične bukve (Fagus sylvatica, L.) u Bosni i Hercegovini. UŠIT FBIH, Sarajevo, Bosnia and Herzegovina and Silva Slovenica, Ljubljana, Slovenia, 229 p. [in Bosnian]

Ballian D, Zukić N, 2011. Analiza rasta provenijencija obične bukve (Fagus sylvatica L.) u međunarodnom pokusu kod Kaknja. Rad Šum Fak Sarajevo 2: 75-91. [in Bosnian]

Barriere G, Comps B, Cuguen J, Ntsiba F, Thiebaut B, 1984. The genetical ecological variability of beech (Fagus sylvatica L.) in Europe. An alloenzymatic study: genetic isolations of beechwoods. In: Improvement and Sylviculture of Beech, Gros-shansdorf, 2450 .

Bogunović S, Bogdan S, Lanšćak M, Ćelepirović N, Ivanković M, 2020. Use of a Common Garden Experiment in Selecting Adapted Beech Provenances for Artificial Stand Restoration. South-east Eur for 11(1): 1-10. https://doi. org/10.15177/seefor.20-07.

Brus R, Horvat - Marlot S, Paule L, Gömöry D, 1990. Genetska variabilnost bukve (Fagus sylvatica L.) v Sloveniji. Zbornih gozdarstva in lesarstva 60: 85-106. [in Slovenian]

Comps B, Màtyàs Cs, Letouzey J, Geburek T, 1998. Genetic variation in beech populations (Fagus sylvatica L.) along the Alp Chain and in the Hungarian Basin. Forest Genetics 5(1): 1-9.

Comps B, Šugar I, Trinajstić I, Plazibat M, 1991. Genetic variation of the Croatian beech stands (Fagus sylvatica L.): Spatila differentiation in connection with the environment. Ann For Sci 48(1): 15-28. https://doi.org/10.1051/forest:19910102.

Ducci F, De Cuyper B, Proietti R, Pâques L, Wolf H, 2012. Reference protocols for assessment of traits and reference genotypes to be used as standards in international research projects. CRA SEL Consiglio per la Ricerca e la Sperimentazione in Agricoltura, $86 \mathrm{p}$.
Fukarek P, 1959. Bukva. Šumarska enciklopedija. Leksikografski zavod FNRJ, Zagreb, pp 149-151. [in Croatian]

Fukarek P, 1970. Areal rasprostranjenosti bukve, jele i smrče na području Bosne i Hercegovine. Radovi ANUBIH 11: 231-256. [in Bosnian]

Gömöry D, Paule L, Brus R, Zhelev P, Tomović Z, Gračan J, 1999. Genetic differentation and phylogeny of beech on the Balkan peninsula. J Evol Biol 12: 746-754.

Gömöry D, Paule L, Shvadchak IM, Popescu F, Sulkowska M, Hynek V, Longauer R, 2003. Spatial patterns of the genetic differentiation in European beech (Fagus sylvatica L.) at allozyme loci in the Carpathians and adjacent regions. Silvae Genet 52(2): 78-83.

Gömöry D, Paule L, Vysny J, 2007. Patterns of allozyme variation in western Eurasian Fagus. Bot J Linn Soc 154(2): 165-174. https:// doi.org/10.1111/j.1095-8339.2007.00666.x.

Gračan J, Ivanković M, 2001. Prvi rezultati uspijevanja obične bukve (Fagus sylvatica L.) u Hrvatskoj. The first growth results of beech (Fagus sulvatica L.) provenances in Croatia. In: Znanost u potrajnom gospodarenju Hrvatskim šumama. Znanstvena knjiga, Šumarski fakultet, Zagreb, Šumarski institut, Jastrebarsko, „Hrvatske šume”, Zagreb, Croatia, pp 175-190. [in Croatian]

Gračan J, Ivanković M, Marijanović H, Perić S, 2006. Istraživanje uspijevanja provenijencija domaćih i stranih vrsta drveća, s osvrtom na međunarodni pokus provenijencija obične bukve (Fagus sylvatica L.). Radovi Šum Inst Jastrebarsko 9: 337-352. [in Croatian]

Hoffmann J, 1961. Ergebnisse eines Anbauversuches mit Buchen verschiedener Herkünfte in Tharandter Wald. Fortstwiss $\mathrm{Cb} / 80$ : 240-252. [in German]

Hussendörfer E, Schütz J-P, Scholz F, 1996. Genetische Untersuchungen zu phänotypischen Markmalen an Buche (Fagus sylvatica L.). Schweiz Z Forstwes 147: 785-802. [in German]

Ivanković M, Bogdan S, Božić G, 2008. European Beech (Fagus sylvatica L.) Height Growth Variability in Croatian and Slovenian Provenance Trials. Sumar List 132(11-12): 529-541. [in Croatian with English summary]

Ivanković M, Popović M, Katačić I, Wuehlisch G, Bogdan S, 2011. Quantitative Genetic Variation of European Beech(Fagus sylvatica L.) Provenances from the Southeastern Europe. Sumar List 135(13): 25-36. [in Croatian with English summary] 
Kajba D, 2003. Unutarpopulacijska i međupopulacijska varijabilnost obične bukve. In: Matić S (ed) Obična bukva (Fagus sylvatica L.) u Hrvatskoj. Akademija šumarskih znanosti \& Hrvatske šume, Zagreb, Croatia, pp 247-263. [in Croatian]

Kleinschmit J, 1985. Results of beech (Fagus sylvatica L.) provenance experiments in Northern Germany. In: Symp. Verbesserung und Waldbau der Buche,Mitteilungen der Bundes-forschungsanstalt für Forstund Hamburg, Germany, 150: 65-84.

Larsen B, 1985. Beechprovenances in Denmark. In: Symp. Verbesserung und Waldbau der Buche, Mitteilungen der Bundesforschungsanstalt für Forst und Holzwirtschaft, 150: 85-91.

Memišević Hodžić M, Ballian D, 2020. Quality of pedunculate Oak Provenances in Bosnian- Herzegovinian provenance test based on branching angle and stem form. Forestist 70: 95-104. https://doi. org/10.5152/forestist.2020.19008.
Memišević Hodžić M, Ballian D, 2021. Morphological and Phenological Variability (Fagus sylvatica L.) in the International Provenance Test in Bosnia and Herzegovina. Sumar List 145(1-2): 19-30. https:// doi.org/10.31298/sl.145.1-2.2

Muhs H-J, 1985 . International provenance trial of beech (Fagus sylvatica L.) from 1983/85. Mitteilungen der Bundesforschungsanstalt für Forst-und Holztechnologie, 3. IUFRO Buchensymposium, pp $77-83$.

Muhs H-J, Von Wühlisch G, 1992. Research on the improvement of beech in the last decade. In: R.E. Rosello (wd) Proceedings of International Congress on Beech. Pamplona 1992. Investigacion Agraria. Sistemas y Recursos Forestales, Vol. I: 311-318.

Popović V, Lučić A, Rakonjac Lj, 2021. Variability of Morphological Traits of European Beech (Fagus sylvatica L.) Seedlings in Serbia. South-east Eur for 12(1): 83-89. https://doi.org/10.15177/ seefor.21-06.

Vidaković M, Krstinić A, 1985. Genetika i oplemenjivanje šumskog drveća. University of Zagreb, Faculty of Forestry, Zagreb, Croatia, pp 213-214. 